Thirty years after privatization: A survey of Icelandic small-boat fishermen

Catherine Chambers ${ }^{1}$ and Courtney Carothers ${ }^{2}$

${ }^{1}$ cat@mail.holar.is; University of Alaska Fairbanks, School of Fisheries and Ocean Sciences, 905 N. Koyukuk Drive, 245 O’Neill Building, Fairbanks Alaska 99775, United States / Hólar University College \& Blönduós Center of Research and Collaboration, Árbraut 31, 540 Blönduós, Iceland; +354 4524029

${ }^{2}$ clcarothers@alaska.edu; University of Alaska Fairbanks, School of Fisheries and Ocean Sciences, 1007 West $3^{\text {rd }}$ Ave, Suite 100, Anchorage Alaska 99501, United States; +1 (907) 375-1412 


\title{
Thirty years after privatization: A survey of Icelandic small-boat fishermen
}

\begin{abstract}
Iceland's nationwide privatized Individual Transferable Quota (ITQ) system is over thirty years old but remains a topic of public and political debate, particularly because of the continued effects on small-scale fisheries. A national survey of small-boat fishermen was distributed to: 1) identify major defining characteristics of participants in ITQ and non-ITQ fisheries, 2) document and examine differences in satisfaction with fisheries management, and 3) evaluate the existing options for newcomers to participate in small-boat fisheries. Survey results indicate that Icelandic small-boat fishermen are engaged in multiple management systems within a wide range of boat sizes. Those who held quota were more satisfied with the current ITQ system compared to those who did not hold quota; however, nearly all fishermen were still critical of fisheries management in Iceland and the two major non-ITQ options of lumpfish and coastal fishing were not perceived to offer significant opportunity for entry-level fishermen. Dissatisfaction stemmed from the lack of decision-making power, a distrust of scientific advice, and the perception that the ITQ system did not serve the purpose of protecting fisheries resources, but was rather oriented only toward economic goals. The dynamic nature of Icelandic small-boat fishing livelihoods and the pervasive negative attitudes thirty years after ITQ implementation demonstrate the need for culturally appropriate and equitable fisheries management schemes where success is measured in social as well as economic and biological terms.
\end{abstract}

Keywords: Iceland; fisheries management; fisheries privatization; Individual Transferable Quotas (ITQs); small-scale fisheries

\section{Introduction}

The privatization of access to marine resources represents a dramatic shift in the ways human societies have traditionally organized around marine resources. Under privatized fisheries, the right to fish, once governed by commons arrangements, becomes a limited and tradable commodity. The push for privatization of marine resources began in the early 1950s with the development of fisheries economics and bio-economic modeling $[1,2]$. In this emerging view of fisheries, overcapitalization was a major problem that led to inefficiencies in the system as too much capital was used to catch fish, dissipating the potential aggregate wealth and potentially threatening the long-term viability of fish stocks. The primary justification behind the implementation of privatization schemes is therefore to reduce overcapitalization by making the right to fish a private commodity [3-8] so that less efficient fishermen sell out of the system, theoretically resulting in a more economically-efficient fishery.

This framing of fisheries that puts economic efficiency as the primary goal can minimize other important social aspects of fisheries systems. In particular, smallscale fishing operations and rural coastal communities can be irreversibly and disproportionately impacted by the transformations generated by fisheries privatization schemes. For example, crew and boat owners lose jobs as increasing costs force small-boat owners to sell fishing rights [9], remaining crew receive less shares [10] or become wage laborers [11], women and migrant workers lose jobs when small-scale on-shore processing facilities close due to decreases in fish deliveries [12], local fishing practices and values become marginalized [13, 14] and 
existing social inequalities in rural communities can deepen, causing tension between those who hold fishing rights and those who do not [15].

As research exploring the social impacts of privatized fisheries continues to accrue $[11,16,17]$, there is evidence that the logic behind privatization - that individuals are inherently self-interested profit-maximizers - does not apply to all small-scale fisheries. Individual private property mechanisms are based on a largely asocial view of how people organize around resources $[18,19]$, and small-scale fishers are constrained by, and operate under, complex cultural, political, and historic aspects in addition to economic considerations [e.g. 20-23]. Fisheries can be a way to make only a small amount of money without the intent to increase production or build up status [24], a flexible opportunity to maintain income in times of few options [20], a rural livelihood that blends small commodity and subsistence production [25], and an activity that weaves together cultural, familial, and historic ties to a way of life not fully centered on commercial gain and full engagement in commercialized fisheries [26]. Small-scale fisheries worldwide are therefore important to creating and maintaining community sustainability through flexible arrangements that respond to local social and environmental conditions [23, 27].

This paper explores the current status of Iceland's small-boat fisheries within the larger context of a national fisheries privatization system to provide a better understanding of the ways privatized fisheries management affects small-boat fishermen's ability to engage in culturally and historically important livelihoods. Privatized access fishery systems can take on many forms and vary greatly in their specific regulations on transferability, species covered, initial allocation, boat sizes, etc. In Iceland, the variation in possible management structures combined with the ease of enacting policies for a comparatively small population of fishers has led scholars, politicians, and others in the public sphere to remark on the "experimental" nature of fisheries privatization [28-32]. In fact, at the time of implementation, the ITQ system was often referred to as a temporary measure to protect fish stocks. Thirty years after fisheries privatization changes began, this so-called experiment has generated dramatic transformations that are still unfolding. Recent scholarship regarding Iceland's fisheries privatization has focused on human rights and the legality of the ITQ system [33], the involvement of stakeholders and power imbalances in the management process [28], the changes in longline fishing practices [34], and fisherwomen's experiences of change [35]. This paper explores the current status of the Icelandic ITQ system with particular focus on small-boat fisheries and fishing livelihoods. First, this paper documents the basic characteristics of individuals participating in the major small-boat fisheries. Second, it explores fishermen's satisfaction with the current management arrangements and examine how individuals take part in governance processes. Third, it assesses the ability of Iceland's smallscale fisheries to support entry-level fishermen. This research aims not to evaluate the effect of Iceland's privatized management system on small-boat fisheries per se, but to understand the legacy of past fisheries management decisions, or "experiments," for individuals who are currently participating in small-boat fisheries.

\section{Icelandic fisheries}

Iceland was one of the first countries to develop a nationwide privatized Individual Transferable Quota (ITQ) system, in which fishermen or companies can buy and sell fisheries quota, which is a percentage of a yearly total allowable catch (TAC) of one species [36]. Before the ITQ system, Icelandic fisheries were managed by various combinations of gear restrictions, area closures, licensing, effort restrictions and 
catch quotas, and were subsidized by the Icelandic government with mechanisms such as loans from public funds and debt restructuring [6, 12, 30]. First instituted with transferability restrictions in the early 1980s to demersal species, the ITQ system became fully transferable and was expanded to the majority of commercial fish species for boats over six Gross Registered Tonnage (GRT) with the 1990 Icelandic Fisheries Management Act, while boats under six GRT were exempt [36]. In general, quota for each species was allotted to vessels based on their fishing record in the three years prior to ITQ implementation. For all species in the ITQ system, the Marine Research Institute (Hafrannsóknastofnun) gives official scientific advice and final TAC decisions are set by the Minister of Industry and Innovation (Figure 1). "Cod equivalents" are a common factor in quota trading, in which other species are given a weighted value in relation to their market value compared to cod.

Administration of the ITQ system and licenses is undertaken by the Directorate of Fisheries (Fiskistofa), which also oversees compliance with other regulations such as area closures and gear restrictions. No discards are permitted in any fishery, and catch from small boats is landed at designated "fish markets" that give real time landing updates to the Directorate of Fisheries and then sell the catch through a centralized daily national auction [37].

After implementation of ITQs, changes in fisheries participation were immediate. Quota consolidated in larger companies and boats, and migrated away from rural communities. Many small-boat owners felt forced to sell out of the system, and public discontent with the equity of privatized fisheries continued to grow [12, 21, 38,39 ]. In 2003, the community quota system (byggðakvóti) was enacted, in which each year, the Ministry gives quota directly to fishermen who will land the fish in particular communities under regulations specific to the community. (There were 7000 tonnes of cod equivalents assigned to the community quota system in the 20142015 fishing year, less than $2 \%$ of the 2015 TAC in cod equivalents). Then in 2004, handline and longline small boats under 15 GT were split away from the large-scale industrial ITQ fisheries in a small-boat ITQ system to counteract the accumulation of quota by large factory trawlers and companies. In 2009, the post-economic crash government instituted a new non-ITQ small-boat hand line season called "coastal fishing" (strandveiðar) in an effort to offer access for newcomers to fishing lifestyles, partly in response to rulings by the United Nations Human Rights Committee on the social equity problems of the privatization of fisheries resources [40], and partly to revitalize small coastal communities that had suffered from loss of ITQs. Coastal fishing is also managed under the Ministry and Directorate of Fisheries, and includes four regions that each have a portion of the same TAC used in the ITQ fisheries (totaling 8,600 tonnes in 2015, less than 2\% of the 2015 TAC in cod equivalents). Coastal fishing with a maximum of four jig machines is allowed for 14 hours per day from Monday to Thursday during May, June, July and August and is subject to a daily catch limit of $650 \mathrm{~kg}$ of cod equivalents of demersal species, mainly cod, saithe, and rockfish. The other non-ITQ fishery, the small-boat spring lumpfish roe gillnet fishery, has always existed outside of the ITQ system and is managed by limited entry licensing as well as days-at-sea (32 continuous days as of the 2015 season), and net length and mesh size restrictions put into law by the Ministry and Directorate of Fisheries (Figure 1).

[Figure 1 here]

As shown in Figure 1, there are five major fishery sectors in Iceland, and four 
of these categories relate to small-boat fisheries: small-boat ITQ, coastal fisheries, community quota, and lumpfish. These categories are not exclusive and there is often overlap in participation between small-boat fisheries, and between large and smallboat fisheries. Currently, small-boat fisheries are defined as long line, hand line, and gillnet boats under 15 meters in length and 30 GT. Shrimp boats, larger long liners, Danish seines, purse seines, and pelagic and bottom trawlers over 30 GT are included in the large-boat ITQ fishery. In 2014, small-boat fisheries consisted of around 1,418 boats (compared to 267 large boats) and employed around 1600 individuals full time. In the 2014-2015 fishing year, the total catch for small-boat fisheries was about $8 \%$ of the total catch landed in Iceland (or 91,740 tonnes, compared to 987,556 tonnes for large-boat fisheries), and $14 \%$ of the small boat catch (or $1 \%$ of the total catch) was landed by non-ITQ fisheries [41].

\section{Methods}

This research explores the experiences and attitudes of Icelandic small-boat fishermen engaged in different fisheries management arrangements under the Icelandic Ministry of Industry and Innovation. Data were collected with a national questionnaire mailed in August 2013 (at the end of the 2012-2013 fishing year, which runs from September-August). It assessed a conceptual framework of themes gathered through earlier phases of ethnographic research in Northwest Iceland (August 2011-August 2013) that included participant observation on fishing boats and fish processing plants, and semi-structured interviews with fishermen, their families, and community leaders. Mailed surveys were chosen as a compliment to the previous qualitative research because surveys collect data from a larger number of individuals that can be extrapolated to a sample population, minimize response effects based on the interviewer [42,43] and can be used to test ethnographic understandings. Salant and Dillman's multi-step process was used to establish four direct contacts with the respondents [43]. After back translating [42] and pre-testing the survey with key informants, first a letter was sent announcing the survey, and then a survey packet was mailed seven days later. Seven days after that a reminder postcard was sent, and finally a second survey packet to those who did not respond four weeks after the first mailing.

The Directorate of Fisheries 2012 license database was used to produce a stratified random list of 500 small-boat fishermen (44\% of the total database) from the listed 1,145 unique addresses of registered small fishing boats (long line, hand line, and gillnet boats under 15 GT). Small boats are technically defined as those vessels under $30 \mathrm{GT}$, but at the time of sampling the majority of boats fell under 15 GT which was therefore reflected in the sampling stratification. Addresses affiliated with large boats (shrimp boats, large long liners, Danish seines, purse seines, and pelagic and bottom trawlers over $15 \mathrm{GT}$ ) were excluded from the sample list. The list of 500 boat owners was stratified to equally sample fishermen in the three main management schemes for small boats in Iceland: small-boat ITQ fisheries (including a "hook and line" ITQ system), lumpfish, coastal fishing, and any combination thereof (Table 1). Community quota holders were not sampled as a specific group because there is significant overlap between community quota holders and small-boat ITQ fisheries, and because community quota can also be given to large-boat ITQ holders. Crew members are not included in the database and therefore the survey sampled only boat owners and license holders. The survey was made up of four sections related to dominant themes in small-boat fisheries identified in earlier research phases: demographics and fishing participation, employment and 
community, fisheries management, and conservation and environment. Questions consisted of Likert scales, multiple choice, and open-ended responses. Differences between quota holders and non-quota holders, fishery type, and other demographic variables were analyzed using Kruskal-Wallis tests to compare differences in continuous data (summed Likert items and income) and Pearson's chi-squared tests to compare differences in categorical data (multiple choice questions). Open-ended responses were coded and analyzed for thematic similarities; exemplar quotes from those responses are presented to give deeper context to the discussion of survey results.

\section{Results and discussion}

\subsection{Survey response and fisheries participation}

Of the 500 surveys mailed, 21 were returned as undeliverable, and 164 were completed and returned for an adjusted response rate of $34.2 \%$ (representing $14 \%$ of the total population of small boat owners in Iceland). This response rate is on the higher end of the average response from mailed surveys to targeted occupational groups in Iceland (25-35\%) (University of Iceland Social Science Research Institute, pers. com.) and is similar to the range of $13-35 \%$ from other recent studies of resource users using a comparable method [44-48]. Surveys were returned from respondents from primary fishery groups within small-boat fisheries (both selfidentified primary small-boat fishery and their participation in the 2013 fishing year) in similar stratified percentages as were sampled (Table 1); however, $11 \%$ of respondents identified as being primarily part of the large-boat ITQ system.

[Table 1 here]

Those who primarily took part in the large-boat ITQ system were therefore accidentally sampled because they also held permits for a small-boat fishery, most often coastal fishing. This reflects a challenge in labeling and surveying Icelandic fishermen for research purposes and also illustrates an important aspect of Icelandic fisheries and a characteristic of many fisheries worldwide: individuals are engaged in multiple fisheries over the year, as well as through the course of their lifetimes. While $11 \%$ of respondents identified their primary fishery to be large-boat ITQ fisheries, a larger number (28\%), actually participated in large boat fisheries in the 2012-2013 fishing year (Table 1), suggesting that participation in a large-boat fishery does not always lead to identification with that fishery. Furthermore, $60 \%$ reported participating in large-boat fisheries at some point in their fishing career, most commonly as a skipper or crew member.

\subsection{Satisfaction with fisheries management}

Although survey respondents were engaged in relatively powerful positions in smallboat fisheries - as quota holders, captains, and owner-operators - dissatisfaction with the ITQ system and its related politics was common in survey results. To assess satisfaction with fisheries management, a seven-item Likert scale (Cronbach's alpha $=0.828$ ) was developed including statements focusing on: fishermen's involvement in management, protection and utilization of fishery stocks, economic efficiency, and the ability of the current system to ensure stable employment in fisheries. Respondents answered using a 5-point scale, " 1 " for aspects they were strongly dissatisfied with and " 5 " for aspects they were strongly satisfied with. The summed score for each respondent was calculated to reflect overall satisfaction with 
management (total range 7-35; $7=$ highly dissatisfied, $21=$ neutral, $35=$ highly satisfied).

Overall satisfaction was low to neutral and there were no significant differences between fisheries (Table 2). Because of the complexity of fisheries participation mentioned above, a fisherman could consider an ITQ fishery his primary fishery even though he mostly rents the quota to land the fish and vice versa: a coastal fisherman could consider coastal fisheries his primary fishery, even though he makes money from leasing quota. Therefore, rather than participation in or identification by a certain fishery, possession of quota itself best predicts satisfaction with fisheries management: those who held quota were more satisfied with current fisheries management (Kruskal Wallis $\chi^{2}=12.511 p<0.001$ ). However, it should be noted that both quota holders and non-quota holders remained at the lower end of the overall satisfaction scale (quota $=18.77$, non $=15.39$ ). The two primary sources of dissatisfaction and proposed alternatives are discussed below.

[Table 2 here]

\subsubsection{Source of dissatisfaction 1: The purpose of the ITQ system}

A major source of dissatisfaction with fisheries management came from tensions regarding the "purpose" of the ITQ system: what its major end goals should have been, compared to how the system is currently operating in practice. The majority of survey respondents $(76 \%)$ were involved in commercial fishing during the time privatization policies were being implemented (1984-1990) and had observed the ITQ system unfolding. Respondents expressed a shared understanding that the ITQ system was originally meant for environmental end goals, but that the focus on economic end-goals tended to overshadow environmental goals, as the following response to an open-ended question highlights: "The quota system has become an economical system, conducted in Excel. It is no longer a system for ecosystem protection and resource utilization."

Although the history behind support for ITQ systems does in fact stem from economic theory, some countries, including Iceland, implemented ITQs in a time of concern over stock depletion. The need for ITQs is often discussed both in terms of stock protection and economic efficiency, and these discourses have become difficult to separate [11, 49]. Increasingly, environmental and conservation rationales are used to justify ITQ implementation, although the linkage between ITQs and positive environmental outcomes is not well supported and many examples show a negative relationship (as reviewed in [11]). In Iceland, legal documents stated that ITQs were meant to be a temporary measure to protect fish stocks in light of declines in the Canadian and Norwegian cod fisheries [40]. However, in practice, the focus of the Icelandic ITQ system has always been on economic efficiency. The neoliberal economic logic is that fisheries contribute immensely to the state of the Icelandic economy as a major export good and therefore increase the overall standard of living to the benefit of the nation as a whole [50].

\subsubsection{Focus on economic end goals leads to unfair leasing arrangements}

One of the mechanisms related to the economic focus of the ITQ system and fishermen's subsequent dissatisfaction is the quota market itself. The ITQ system in its present form was viewed by many respondents to be a source of corruption that continues to unfold, as the following survey responses illustrate: 
Managing a fishery is necessary, but they should abolish quota, that's where you find the most corruption.

This is all that has changed: the quota system is unfair and makes things harder for those who are not doing the money-laundering.

In small-boat fisheries, accusations of corruption, money-laundering and unfair business practices are most often related to the practice of quota renting and leasing. Leasing arrangements create inequity in fishing communities [51] and our previous ethnographic research suggested that details about quota ownership, renting, and leasing would be difficult and sensitive data to collect and therefore the following data do not reflect the complex relationships between quota renters and holders and between communities. Those who rent fear being viewed as somehow less of a fisherman, or as someone not able to take care of their own fishing business. Those who hold quota and lease it out fear being seen as greedy, or as making unethical business transactions by leasing or selling quota away from their home community. The following comments from different respondents help to illustrate experiences of quota rental:

Only a small number of individuals have control over all the quota in the country and they seem to not be able to share even a single kilo with others. They seem to see every increase in quota as their own property and at the same time they say that they cannot pay a normal fee for the resources, but still they themselves have dividends that are even higher than the resource fee. Still they are able to rent out the quota to fisheries at a price that is half or even $2 / 3$ higher than the market price [of the quota itself]. This needs to be changed. This is unfair to the nation.

Not everyone sits at the same table in all fisheries systems. The renters have to pay all the same fees (licenses, harbor fees, etc.) as those who have had quota allocated to them for free over the years. On top of that they have to pay the rent for the quota, which is out of this world-so there is little left to live off of.

How can it be that the possessor of quota, however he might have got it, can rent it out - as an example, cod for $200 I S K / \mathrm{kg}$ - but the one catching the fish, with all included costs (boat, crew, equipment, labor) gets perhaps 260 ISK for the kilo. The best fishing business is probably the one that can rent out as much as they can without all the extra costs.

You cannot become anything else than a slave. Personal security is not good. The owners of the quota can take it away whenever they want and leave the skipper and crew unemployed.

Our results suggest that just over half of respondents (53\%) did not hold quota, and $25 \%$ of non-quota-holders rented quota. On the other hand, $49 \%$ of those who hold quota also rent quota, and $47 \%$ of quota holders reported leasing anywhere from $2-100 \%$ of their quota out (although $15 \%$ left this question unanswered). Therefore those who hold quota are more likely to rent additional quota (Pearson $\chi^{2}=12.867, p$ $<0.001)$. The renting market therefore consists mainly of those already invested in the quota system, rather than those who do not hold quota but participate in ITQ fisheries by renting from quota holders. Others have suggested that "contract fishing" 
has declined over time [50]. The findings of this study suggest that it may be more appropriate to think of the quota rental market as having changed from "contract fishing" by those who do not hold quota to "semi-contract fishing" by those that do hold at least some quota. These individuals do not hold "enough" quota for one reason or another, and are therefore subject to the same leasing practices that create inequity as those who do not hold quota.

\subsubsection{Focus on economic end goals leads to discards and the "tragic commons"}

A second mechanism related to small-boat fishermen's dissatisfaction with the purpose of the ITQ system with focus on economic end goals can be seen in the environmental concerns about ITQ management. There is a general consensus in the scientific community that cod, the single most important species in Iceland, was overfished in the 1970s and 1980s. Over 500,000 tonnes of cod were landed in 1955, and close to 450,000 tonnes in 1981 [52]. After the implementation of the ITQ system for cod in 1984, cod landings regularly exceed the TAC, and often that TAC exceeded the TAC recommended by the Marine Research Institute. In the late 1990s, there was continued concern over the collapse of Atlantic cod stocks [53] and the Harvest Control Rule (HCR) for cod was enacted in 1996, which now states that the TAC for cod must be a direct calculation of $20 \%$ of the biomass of year 4 and older cod calculated by the Marine Research Institute. TACs and landings continued to decline more or less until 2009, but since have been steadily increasing and the 20152016 fishing year TAC is set at 239,000 tonnes [52]. Currently, there is a general upward trend of spawning stock biomass and recruitment, suggesting that, at least by these measures, the cod stock is performing well, and projections show cod spawning and reference stock biomass increasing to pre-1980 levels by 2019 [52].

Many fishermen, however, view the decrease in overall cod catches compared to the 1980s as a cause for concern. Fluctuations in the cod stock can be caused by a variety of factors, such as environmental regimes shifts that influence prey availability or water temperature, as well as overfishing or other human activities. The primary environmental concern of small-boat fishermen was not overfishing as such, but the discarding of catch and the potential related negative impacts on fish stocks, as explained through the following comments from different respondents:

The system is profitable and efficient from the business operations perspective, the biggest problem of this system is the bad treatment of the natural resources.

The "tragic commons" is still a problem. In the way fishermen treat the natural resource, like discarding fish. I have witnessed these things and many others have told me similar stories. One example I know of happened aboard a trawler owned by one of the big fisheries that got a lot of small haddock in their nets. They took all the big ones, then the smaller ones were dumped back into the ocean. Instead of moving to another location, they threw the nets in the same place and did the same thing when the nets came back up. An identical case also happened on another trawler with medium-sized cod. This is the result of the regulations that states that ships can bring in 5\% more than their quota (and no less than 50\% of their quota); the fishermen started picking out the biggest fish and throwing out the small ones. There are many more stories just like these and it makes it difficult to see how these regulations are supposed to protect and sustain the fish-stock. 
A lot of fish is dumped. Cod has been dumped, and haddock, all depending on what types they have quota for. Then they come to shore with specific amounts of fish that give the most money and the other fish is dumped.

The "dumping", or high-grading, of lower value fish and the discard of species fishermen do not have quota for can be a sensitive subject to study because legally all catch must be landed and therefore it can be difficult to obtain accurate discarding data. Prior estimates of high-grading in Iceland are low for large-boat fisheries [54] as well as small-boat fisheries [55]. However, earlier phases of our research suggested that the presence of high-grading and discarding of no-quota catch was something about which small-boat fishermen were concerned. To obtain some estimate of the presence of discarding in small-boat fisheries, survey respondents were asked to report simply the presence or absence of discarding in the fisheries in which they participated in during 2013. Those who participated in coastal fishing reported the lowest incidence of discarding (30\% of coastal fishers reported some form of discarding), followed by small-boat ITQ (39\%), lumpfish (49\%), and largeboat ITQ (59\%). The frequency or amount of discarding would be difficult to estimate using a mailed survey technique, and therefore these self-reported discard data may not fully clarify discarding practices or their ecological significance. However, the mere acknowledgement of discarding activity by the small-boat fishermen themselves in both the ITQ and non-ITQ fisheries alike provides a counterexample to literature focusing on ITQs as a conservation tool [56-57] and supports previous analyses suggesting that private ownership itself does not always ensure care for the resource and solve issues of the tragedy of the commons, and in fact may encourage destructive practices like discarding [58-64].

Those engaged in ITQ fisheries become the rational actors that the economic logic of the system is based upon, making the best choice of the options available to them to ensure the economic viability of their fishing business, sometimes engaging in environmentally negative behaviors. In the same way, those in non-ITQ fisheries are similarly bound to the ITQ system due to Iceland's landing and no-discard rules: as bycatch comes up for which they do not have quota, they are forced to either illegally discard the catch, rent quota for the day to land that particular species, or pay the penalty of landing catch without quota. Again, whether they like it or not, sometimes the best economic option for a non-ITQ fisherman is to discard his catch. The dissatisfaction of small-boat fishermen concerning end goals of fisheries management is therefore due to the fact that they felt forced to engage in discarding as a result of the current ITQ scheme, although they recognized the potential negative environmental impacts, as one respondent explained:

The government has certainly tried to limit the amount of fish thrown away but at the same time they have tried to undermine the issue and some even tried to suppress it. The spokesmen for the quota system have tried to deny all suggestions for improvements, since they experience it as an attack on the system in a whole, but not a smaller issue that can be fixed. The clearest case of that happened a decade ago. Some fishermen video-taped others dumping small fish back into the ocean and brought it to the media. They had no choice since fishing was their livelihood and they, just like others, had to feed their families. The orders for the dumping came from the captain that had received his orders on land, it was based on the situation of quota on the ship. When the fishermen had enough of this they filmed that video. After the news story broke, other 
similar cases seemed to pop up from everywhere and others wanted to come forward and tell their stories. This came to an end quickly when the head of the Directorate of Fisheries stepped up and was interviewed on the television, he stated that fishermen caught dumping fish in the ocean would be prosecuted. In other words, he said that the pawns that were made to dump the fish would be held responsible, but not the ones giving the orders. By doing this they prevented more stories surfacing and a general discussion on the matter. It would be fun to compare this to the Icelandic bank collapse in 2008. What would people say if a judge stated that he was going to make the cashiers and the employees of the banks responsible for the criminal activity in the banks? Or even attack all those who would come forward and reveal the criminal activity they had witnessed amongst the executives?

\subsubsection{Source of dissatisfaction 2: Decision-making power}

The second major source of dissatisfaction with fisheries management was related to the governance of Icelandic fisheries itself. Governance can be defined as the social and political institutions that are involved in fisheries, while management can be considered as the specific arrangement for fisheries decided upon by the governance process [27]. In many respondents' minds, the ITQ system itself had been linked with the governance institutions so that it was impossible to think of one without the other. As one respondent wrote: "[In the past] I could be in charge of my own fishing, instead of leaving it to the theories of not-so-bright politicians. " Put another way, small-boat fishermen perceived the ITQ system itself as no different from the human political institutions and processes that govern the rules surrounding the ITQ system. This is due to the specific relationship among the players involved in the Icelandic fisheries decision-making process.

The theoretical design of the ITQ system accounts for the buying and selling of quota to be carried out under market dynamics, leaving the Marine Research Institute with the task of recommending a yearly TAC upon which the quota percentages are based. This creates a simplified management system, where fishermen (or social science data focused on fishermen and fishing communities) have no official input. As Christensen et al. note: "In Iceland, fishermen formally play a small role in the management system, but in practice they have easy and direct access to the Minister, who has the final say in most matters" [50]. In practice, however, this direct and easy access is not equal across all types of fishermen, and the TAC decisions by the Ministry and specifics of regulations set by the Directorate of Fisheries can depend heavily upon lobbying by specific trade unions (see [28] for a detailed analysis of stakeholder engagement). For small-boat fishermen, there is one main union (National Association of Small Boat Owners: Landssamband smábátaeigenda), and most local chapters gather once a year to discuss issues. Each local chapter sends a report to the chairman, who then speaks for all small-boat owners at the national level. The infrequent and relatively disengaged involvement cannot respond to current issues in a timely matter, as this survey comment illustrates:

A man came by the other day to close a big area for coastal fishing - because of one boat that had too much fish - then they went to the next fjord and were going to close off an even bigger area. Then they closed off the whole area, it wouldn't have been necessary, this is arrogance and abuse of power. 
The exclusion of fishermen themselves from formal and flexible decisionmaking processes has led to dissatisfaction and distrust in governance institutions as small-boat fishermen, particularly those in rural communities, do not often have easy and direct access to the Minister. A sense of helplessness permeated the surveys with comments such as: "They are always changing the rules," and "We don't make the rules." Fishermen in all small-boat systems generally perceived little or no agency or power in the decision-making process:

The Marine Research Institute and the Directorate of Fisheries are controlled by men that think they know everything but don't know much and don't listen to anything, that's my experience.

Increased involvement of others has often made the fisherman's life harder through the years and their visions are not always the same.

The Marine Research Institute is dangerous for the industry. The ones who sit at the desks don't know anything about us and want to control everything, we are not listened to. They close areas without knowing what they are doing.

The Marine Research Institute is in an ivory tower with their consultations that not always but many times are way out of tune in regards to what is happening at sea. But they seem to have created their place with the government where their conclusions are not questioned.

The majority of respondents (87\%) agreed with the Likert statement "The government needs to consult with fishermen when it comes to fisheries management" (Figure 2), but did not agree that need was actually taken into account in making policy. There is no guarantee that local comments or concerns are brought up officially, and even if they were, the Ministry and the Directorate of Fisheries are under no formal obligation to take union lobbies or fishermen's knowledge into account whether the topic be area closures, season openings, gear restrictions, or stock health and status. The mismatch between fishermen's knowledge and the scientific research was highlighted by many respondents as a specific reason for dissatisfaction with the governance process:

You can calculate the business environment. But the size of a fish-stock? How can people predict the size of the stock in the ocean when they cannot count all the reindeer in the country that you can see with your own eyes and are only located on the east coast.

Fishermen need to be listened to, trawl surveys cannot be the only criteria used, because the trawlers are always using the same areas and the same equipment.

[Figure 2 here]

The lack of inclusion of fishermen's knowledge and the unequal power in the decision-making process highlight a paradox in neoliberal fisheries theories. Some scholars have explored the theoretical groundings of fisheries rights privatization that allow for the reduction of the role of the state by the transferring of fishing right 
allocation power to the market $[16,65]$. These scholars highlight the paradox that while the market is seen as the fair arbiter of fishing rights, often privatization systems require oversight by political institutions that can in fact further existing inequalities or create new unequal power arrangements. Scholars question whether equality and limitations on commodification can exist in general neoliberal fisheries management and governance [66-68], but in Iceland it has in fact increased political divide, creating both unequal political governance arrangements as well as differential impacts on small-boat fisheries.

\subsubsection{Alternative management arrangements}

In a multiple choice question, $38 \%$ of respondents stated that an ITQ system was the best future arrangement for small-boat fisheries in Iceland; among them, 26\% thought quota should not be transferable, but the rest were generally satisfied with the basic idea of an ITQ system. The other $62 \%$ believed that small boats should operate under a completely different system, and listed those ideas in an open-ended question. Those responses were then coded and categorized into four major options. The most popular option was some kind of regional system, followed by temporal limits, catch limits, and a national quota that is rented from the government every year with builtin breaks to newcomers or by local area (Figure 3).

[Figure 3 here]

The devolution of power to a regional system was explained by many respondents to not only offer a solution to developing a more equitable management system, but a more democratic governance system as well, where local councils would have control of community and regionally-based quota in addition to the decision-making process itself. The popularity of a regional control system is a slight contrast to the findings of Kokorsch et al. [28], who sampled stakeholders from Icelandic large and small-boat fisheries as well as processing workers and others such as office-workers in fisheries support services. Among all stakeholders, the study found a non-transferable quota system was most preferred rather than a regional system [28]. This difference in findings highlights the importance of understanding the views of various stakeholders, and specifically those more under-represented groups such as small-boat fishermen. In fact, our study found that 58\% of small-boat survey respondents felt ITQs were the best option for large boats, which further exemplifies the importance for variable management schemes for different kinds of fisheries. Furthermore, there was a common belief among survey respondents that large and small fishing operations could co-exist given the right management scenario, as one fishermen wrote:

Nature has done it for us, good fisheries can have both-one end you have large trawlers going after open water species and then small boats are close to shore. Those close to the coast will always be limited by gear, small boat size, weather - so you don't need to worry much about them.

This acknowledgement of the different sizes and types of fisheries with corresponding management systems is similar to warnings by critics and proponents alike that ITQs are not a one-size-fits-all solution [21, 68, 69]. In Iceland, however, although there are some policies aimed specifically at small boats and rural communities, the governance process and management arrangement are based upon 
free transferability of access rights for both large and small boats. Seminal research in the early stages of the ITQ system found that fishermen strongly resisted fisheries privatization on moral grounds, considering it evil or immoral because individual labor was devalued with the increasing focus on capital accumulation through private ownership [70]. The concept of ownership continues to be a complex theme to explore in Icelandic fisheries. In response to the Likert statement "Ownership is the best way to protect fishery resources," $49 \%$ disagreed, but $25 \%$ were neutral and $26 \%$ agreed, and there were no statistical differences between fishery type or quota ownership (Figure 2). The lack of clarity in these responses is most likely due to the fact that recent public discourse in Iceland regarding fisheries management and the de facto ownership of marine resources has acknowledged the shortcomings of private and corporate ownership, calling for an exploration of the options in state or community collective ownership. The question for many small-boat fishermen therefore seems to be not whether fish stocks or the right to fish can be owned, but who can own them. The ideas of regional management and community quotas are based upon ownership, but have less focus on accumulation and capital gain as the current private ownership system. This important difference led Christensen et al. [50] to conclude: "... the opportunity to manage fisheries by for example adaptive, regional, species-specific criteria as a complement to the ITQs exists. Such measures might detract from the economic efficiency of the current system, but could address some of the emerging and pressing biological and social issues facing the system."

\subsection{Access to fisheries resources}

Survey respondents valued the fact that they could participate in fisheries as a tie into Icelandic national culture. In fact, $94 \%$ agreed that fisheries are a part of the Icelandic national identity (Figure 2). The act of fishing was often referred to as something that should remain an option for all Icelanders to try. One respondent summed it up like this:

It is good for everybody to try something within the fishing industry at least once. Fishing is in our blood. From person to person — and this will make a living for the nation for a long time.

As in many other cultures around the world, fishing is an inherited livelihood. Individuals reported a mean of 3.2 generations of family engaged in fishing; however, many responses to the question "how many generations of your family have been involved in commercial fisheries?" suggested much deeper connections to fishing livelihoods, e.g., answers included: "since the 1800s," "from the beginning of Icelandic history," "since the oldest men remember", "all mine before and after," and sometimes simply "all." There were no significant differences between fishery group or quota-holding and generations fishing, suggesting at least one cohesive thread in Icelandic small-boat fishermen: fishing is an activity deeply-rooted in family and personal history. As one respondent wrote: "I was raised in a family of fishermen and therefore fishing is like a drug. You never get rid of the interest in fishing." Although fishing is part of a national identity and access to fish resources is a constitutional right of all Icelanders [40], the start-up costs can be overwhelming for newcomers who wish to try fishing. The following sections explore the specifics of these barriers to entry often linked with ITQ systems, and assess the current options for newcomers in non-ITQ fisheries. 


\subsubsection{Barriers to entry}

One common aspect of ITQ systems is the decreased access for newcomers to enter fisheries. Other research shows the negative impact of fisheries privatization schemes on those attempting to enter fisheries [9, 15, 71-73] as original quota holders stay in the system and access for newcomers is limited. This "greying of the fleet" is present in Icelandic small-boat fisheries as well. As one respondent wrote, "There are very few young men and women who can afford to pay that much to work."

Respondents explained that as the quota became tied up in exchange between larger companies paying higher prices, the cost of purchasing quota became prohibitive to new small-boat fishermen.

Youth and newcomers to fisheries represent a striking gap in the survey responses and the authors have no reason to expect a response bias as many smallboat fishing companies are single-person entities. Ten out of the 164 respondents had been fishing for less than 5 years, and three were under the age of 30 . Survey respondents were on average 58 years old (range $21-80, \mathrm{SD}=13$ ) and had over 30 years of fishing experience (range $2-61, \mathrm{SD}=16$ ). And although $44 \%$ of survey respondents had worked as crew at some point in their career, averaging 13 years crew experience, the majority was now skippers or captains, representing perhaps the last generation of small-boat fishermen to work their way up through fisheries as was once common, from crew to skipper to owner. At the same time, survey respondents also reflect something of an anomaly; they are the generation that was gifted the original quota and have fought to keep that quota and build their fishing businesses.

As the quota holders' fishing businesses grew, so did their percentage of income from fisheries. Respondents who held quota earned significantly more of their income from fisheries compared to those who did not hold quota (Kruskal-Wallis $\chi^{2}=$ 17.296, $p<0.001$ ), suggesting a key difference between quota-holding and non-quotaholding small-boat fishermen. In popular discourse, the former are considered fulltime fishers, the latter as part-time or leisure fishermen (although they sell the catch for profit). About a fourth of survey respondents (27\%) fished exclusively outside of the ITQ system in the 2012-2013 fishing year (meaning lumpfish, coastal fishing, or combining the two, and did not rent or hold quota) and they made less than half of their yearly income from fisheries. However, the common framings of full time or part-time fishermen are limited and our data reflect on a slightly more nuanced understanding of fishing as an occupation. There was strong agreement $(75 \%)$ among all respondents to the Likert statement "it is not possible to make enough money in fishing for the year outside the ITQ system" (Figure 2). More tellingly, those who did not hold quota were more likely to respond "no" to the question "Would you advise a young person to enter your primary fishery?" (Pearson $\chi^{2}=5.076, p=0.024$ ).

The question is therefore whether fishermen have the upward mobility to move from part-time or newcomer to a full time quota-holding fisherman. This flexibility is an important and traditionally common trait in small-scale fisheries [23, 27]. In response to the statement: "I have the flexibility to join other fisheries if my primary fishery is not doing well in any given season," those engaged in non-ITQ fisheries disagreed most strongly (Figure 4). Those that were engaged in all three small-boat fisheries perceived themselves to be most flexible, suggesting that individuals who participate in ITQ fisheries have the flexibility to engage in additional non-ITQ fisheries, not the other way around. The non-ITQ fisheries and their limited ability to support upward mobility of newcomers into small-boat fisheries are reviewed below. 
[Figure 4 here]

\subsubsection{Non-ITQ option for newcomers: Coastal fisheries}

Coastal fishing is a relatively new system and participation varies year to year as the system settles. The majority (73\%) of survey respondents had tried coastal fishing at some point while just over half (56\%) fished it in 2012-2013, 19\% exclusively (Table 1). While the coastal fishing system was designed to allow open entry into small-boat fisheries, our survey suggests it is not enough to meaningfully impact true newcomers in fisheries. For example, the average age of the 31 survey respondents who fished coastal fisheries exclusively in 2013 was 60 years old, and they had 30 years of fishing experience, which is no different from the average of all small-boat fishers combined. Coastal fisheries participants made on average less than one fourth of their income from fisheries and $67 \%$ would not advise a young person to enter that fishery. Respondents felt it was simply too hard to make money in coastal fisheries and made comments such as, "This is only for people who really enjoy this and are passionate about it because it is not very profitable," and "I have a son that bought a boat a year ago [to fish coastal fishing]. He's fishing as much as he can but it just doesn't work for him without my help." The high cost of participating in coastal fisheries comes from the costs of boats, jig machines and bait, captain licenses and safety regulations, plus fuel and time spent away from home - a fourth of coastal fishing participants lived in larger areas and fished in smaller communities. Finally, as was noted above, large-boat fishermen were accidently included in the survey because they held coastal fishing permits. These details regarding cost and flexibility suggest that coastal fisheries most benefit individuals who are already engaged in fishing or who are financially established in other trades or professions, not newcomers in rural communities.

\subsubsection{Non-ITQ option for newcomers: Lumpfish}

The lumpfish fishery can be equally restricting. In the 2012-2013 fishing year, 10\% of survey respondents fished only lumpfish, and their median income from fisheries was between 20-30\% of total yearly income. Although lumpfish is not part of the ITQ system, it is managed by limited licenses (under 500) that can be expensive and not often available for sale, and additional costs come from captain licensing and safety regulations. Because it is a seasonal roe fishery, lumpfish fishing has historically been combined with other fisheries, and participation can vary greatly year to year based on roe price forecasts. Respondents did not consider it a true entrylevel fishery that allows participants to save up for investment in more year-round fisheries. Lumpfish fishers were split on advising a young person to enter fisheries; those who answered "no" cited short seasons, increasing costs and rules, and low or fluctuating price for roe. The half who would advise a young person to enter the lumpfish fishery commented that it was meaningful work, fun, and new entrants were important to maintain fishing knowledge. Our earlier phases of ethnographic data also suggest that lumpfish fishing is host to unique historical and cultural aspects such as passing along knowledge, and in that way has always been considered a very different fishery from other commercial fisheries, where participation is not focused on the intent to become a full-time fisherman.

\section{Conclusion}


A number of concerns facing small-boat fishermen are the result of Iceland's ongoing neoliberal experimentation in fisheries. An experiment implies a temporary situation that could be discarded if the experiment results were unfavorable. What supposedly began as an experiment, however, has taken hold in an important way and the ITQ system is entrenched and difficult to change. The specific mechanisms that lead to negative impacts and experiences for small-boat fishermen and rural communities were not one time shocks to a system that otherwise has since reorganized, but continue to affect small-boat fisheries 30 years after initial privatization in Iceland.

This research has shown that: 1) Icelandic small-boat fishermen have important cultural, historical and non-economic connections to fishing, 2) quota holders and non-quota holders alike express dissatisfaction with fisheries management because the focus on economic end goals tends to overshadow other biological or social management goals, and 3) cost and access barriers exist in the non-ITQ fisheries as well as ITQ fisheries.

While this research has detailed the complexity of small-boat fishermen and fisheries, the major thread related to small-boat fishing today is the design of the governance system. Icelandic small-boat fishermen are engaged in multiple fisheries and have a wide range of experience and knowledge, but at the same time are completely separated from the decision-making process, which is essentially the same for ITQ and non-ITQ fisheries alike. Although small-boat fishermen are not without political preferences, their voices are under-represented in current governance arrangement. This research has shown that when natural resource users are disengaged from governance processes, and when local concerns are not addressed, the legitimacy of the governance system is devalued - therefore threatening not only the long term sustainability of the resource but violating principles of equity and human rights as well. This chronic underrepresentation can be offset by alternative forms of management and the creation of opportunities for knowledge transfer to the next generation and a space for their inclusion in current fisheries.

Bottom-up fisheries management, especially in small-boat and small-scale fisheries with local and regional characteristics can empower local fishermen to make environmentally, economically and socially wise decisions in their fishing operations, as well as benefit rural fishing communities that are so culturally, historically and economically dependent on fisheries. An updated, flexible fisheries governance system that would allow for newcomers and larger participation in year-round fisheries would offer more secure access and employment to culturally important livelihoods, as well as deter negative environmental behavior based on economic incentive related to a national ITQ system. Co-management or other forms of participatory management would create a platform for discussion or incorporate fishermen's knowledge in decision making processes, particularly from small-boat fishers who - as this research has shown - access fisheries resources in different ways, times, and who have vested cultural and historic ties to fisheries. Paving a path towards truly sustainable fisheries means taking the unique and dynamic social and cultural aspects of small-scale fisheries into account.

\section{Acknowledgements}

Thank you very much to the community members, fishermen and their families in Northwest Iceland who participated in the earlier interview phases of this research and to the fishermen all around Iceland who completed the survey. Thank you to Guðrún Helgadóttir, Anna Karlsdóttir and Sigríður Ólafsdottir for survey design 
advice and translation, to Erla Hrönn Harðardóttir for survey data translation, and to Margret Rún Auðunsdóttir for survey data entry. The manuscript was greatly improved by comments from Keith Criddle, Andy Seitz, Guðrún Helgadóttir, and two anonymous reviewers. The authors also thank Evelyn Pinkerton, the editor of this special issue, and organizer of the special session at the $2^{\text {nd }}$ World Small Scale Fisheries Congress in Merida, Mexico in 2014 (sponsored by "Too Big to Ignore") where this paper was first presented. This research was supported by the National Science Foundation Arctic Social Sciences Program (Award \#1304681), the National Science Foundation Marine Ecosystem Sustainability in the Arctic and Subarctic (MESAS) IGERT program (Award \#DGE-0801720), the Fulbright Student Program, and the Leifur Eiríksson Foundation Scholarship.

\section{References}

[1] Gordon, H. S. 1954. The economic theory of a common-property resource: the fishery. Journal of Political Economy 62: 124-142. http://www.jstor.org/stable/1825571

[2] Scott, A. 1957. Optimal utilization and the control of fisheries. Pp. 42-65 in The Economics of Fisheries, ed. R. Turvey and J. Wiseman. Rome: FAO.

[3] Árnason, R. 1995. The Icelandic fisheries: evolution and management of a fishing industry. Oxford: Fishing News Books.

[4] Christy, F. 1973. Fishermen quotas: a tentative suggestion for domestic management. Law of the Sea Institute Occasional Paper 19. Kingston: University of Rhode Island.

[5] Christy, F. 1996. The death rattle of open access and the advent of property rights regimes in fisheries. Marine Resource Economics 11: 287-304. http://www.jstor.org/stable/42629171

[6] Danielsson, A. 1997. Fisheries management in Iceland. Ocean \& Coastal Management 35(2-3): 121-135. DOI: 10.1016/S0964-5691(97)00029-X

[7] Hannesson, R. 2005. Rights based fishing: use rights versus property rights to fish. Reviews in Fish Biology and Fisheries 15(3): 231-241. Doi: 10.1007/s11160005-4870-3

[8] Scott, A. 1999. Fishermen's property rights. in Arnason R. and H. H. Gissurarson (eds.), Individual Transferable Quotas in Theory and Practice. Reykjavik, Iceland: Institute of Economic Studies, University of Iceland.

[9] Rosvold, E. 2007. Graying of the Fleet: Community Impacts from Asset Transfers. In Alaska's Fishing Communities: Harvesting the Future, ed. Paula Cullenberg. Anchorage, Alaska: Alaska Sea Grant College Program.

[10] Fina, M. 2011. Evolution of Catch Share Management: Lessons from Catch Share Management in the North Pacific. Fisheries 36(4):164-177.

[11] Carothers, C., and Chambers, C. 2012. Fisheries privatization and the remaking of fishery systems. Environment and Society: Advances in Research, 3, 39-59. DOI: http://dx.doi.org/10.3167/ares.2012.030104

[12] Karlsdóttir, A. 2008. "Not sure about the shore! Transformation effects of individual transferable quotas on Iceland's fishing economics and communities." Pp. 99-117 in Enclosing the Fisheries: People, Places, and Power: American Fisheries Society Symposium 68, ed. M. Lowe and C. Carothers. Bethesda, MD: American Fisheries Society.

[13] Langdon S. Foregone harvests and neoliberal policies: Creating opportunities for rural, small-scale, community-based fisheries in southern Alaskan coastal villages. Marine Policy 61: 347-355. doi:10.1016/j.marpol.2015.03.007 
[14] Jenkins, D. Impacts of neoliberal policies on non-market fishing economies on the Yukon River, Alaska. Marine Policy 61: 356-365.

doi:10.1016/j.marpol.2015.03.007

[15] Carothers, C. 2015. Fisheries privatization, social transitions, and well-being in Kodiak, Alaska. Marine Policy 61: 313-322.. doi:10.1016/j.marpol.2014.11.019

[16] Pinkerton, E. and Davis, R. Neoliberalism and the politics of enclosure in North American small-scale fisheries. Marine Policy 61: 303-312. doi:10.1016/j.marpol.2015.03.025

[17] Olson, J. 2011. Understanding and contextualizing social impacts from the privatization of fisheries: an overview. Ocean \& Coastal Management 54(5): 353-363. doi:10.1016/j.ocecoaman.2011.02.002

[18] Singer, J. 2000. Entitlement: The paradoxes of property. New Haven, CT: Yale University Press.

[19] Wilk, R. 1996. Economies and Cultures: Foundations of Economic Anthropology. Boulder, CO: Westview Press.

[20] Carothers, C. 2010. Tragedies of commodification: transitions in Alutiiq fishing communities in the Gulf of Alaska. MAST 9 (2): 95-120.

[21] Davis, A. 1996. Barbed wire and bandwagons: a comment on ITQ fisheries management. Reviews in Fish Biology and Fisheries 6(1): 97-107. Doi: 10.1007/BF00058522

[22] Waldo, S., Berndt, K., Hammarlund, C., Lindegren, M., Nilsson, A. and Persson, A. 2013. Swedish coastal herring fisheries in the wake of an ITQ system. Marine Policy 38, 321-324. doi:10.1016/j.marpol.2012.06.008

[23] Kooiman, J., and Centre for Maritime Research. 2005. Fish for Life: interactive governance for fisheries. Amsterdam: Amsterdam University Press.

[24] St. Martin, K., 2007. The difference that class makes: neoliberalization and noncapitalism in the fishing industry of New England. Antipode 39 (3): 527-549. DOI: $10.1111 / \mathrm{j} .1467-8330.2007 .00538 . x$

[25] Reedy-Maschner, K. 2009. Entangled livelihoods: economic integration and diversity in the western Arctic. Alaska Journal of Anthropology 7(2):135-146.

[26] Davis, R. 2014. A Cod Forsaken Place? Fishing in an Altered State in Newfoundland. Anthropological Quarterly, 87(3): 695-726.

[27] Jentoft, S. Chuenpagdee. R. 2015. Interactive Governance for Small-Scale Fisheries. Mare publication series 13. Springer International Publishing Switzerland. Doi 10.1007/978-3-319-17034-3

[28] Kokorsch, M., Benediktsson, K., and Karlsdóttir, A. 2015. Improving or overturning the ITQ system? Views of stakeholders in Icelandic fisheries. Maritime Studies 14:15. doi: 10.1186/s40152-015-0033

[29] Benediktsson, K. (2014). Nature in the "neoliberal laboratory. Dialogues in Human Geography 4(2), 141-146.

[30] Matthíasson, T. 2003. Closing the open sea: Development of fishery management in four Icelandic fisheries. Natural Resources Forum: 27(1)1-18. DOI: $10.1111 / 1469-8219.00065-\mathrm{i} 1$

[31] Pálsson, G. 2006. Nature and society in the age of postmodernity. In Biersack, A and J. Greenberg, eds. Reimagining political ecology. Duke University Press.

[32] Eypórsson, E. 2000. A decade of ITQ-management in Icelandic fisheries: consolidation without consensus. Marine Policy 24(6): 483-492. doi:10.1016/S0308-597X(00)00021-X 
[33] Einarsson, E. 2015. When fishing rights go up against human rights. In Gambling Debt: Iceland's rise and fall in the global economy. Eds Durrenbuger, E.P., Pálsson, G. University Press of Colorado, Boulder.

[34] Mariat-Roy, E. 2014. When fishing means resilience: the evolution of small boat fishing pratices in Iceland since 1990 and the new development of longline fishing. Polar Record (50): 421-429. Doi: 10.1017/S0032247414000321

[35] Willson, M. 2014. Icelandic Fisher Women's Experience: Implications, Social Change, and Fisheries Policy. Ethnos 79: 4.

DOI:10.1080/00141844.2013.783606

[36] Árnason, R. 2005. Property rights in fisheries: Iceland's experience with ITQs. Reviews in Fish Biology and Fisheries 15(3): 243-264. Doi: 10.1007/s11160005-5139-6

[37] Anonymous. 2014. Stjórn fiskveiða 2014/2015: Lög og reglugerðir (Fisheries Management 2014/2015: Laws and regulations). Atvinnuvega- og nýsköpunarráðuneytið (Icelandic Ministry of Industry and Innovation), Reykjavík, Iceland.

[38] Eypórsson, E. 1996. Theory and practice of ITQs in Iceland - privatization of common fishing rights. Marine Policy 20(3): 269-281. doi:10.1016/0308597X(96)00009-7

[39] Pálsson, G., and A. Helgason. 1995. Figuring fish and measuring men: the individual transferable quota system in the Icelandic cod fishery. Ocean \& Coastal Management 28(1-3): 117-46. doi:10.1016/0964-5691(95)00041-0

[40] Einarsson, N. 2011. Fisheries governance and social discourse in post-crisis Iceland: responses to the UN Human Rights Committee's views in case 1306/2004. The Yearbook of Polar Law: 3. DOI: 10.1163/22116427-91000068

[41] Statistics Iceland. Fishing vessels. Accessed 12 Nov 2015. http://www.hagstofa.is/en/statistics/business-sectors/fisheries/fishing-vessels/

[42] Bernard, H.R. 2006. Research methods in anthropology: qualitative and quantitative approaches. Lanham, MD: AltaMira Press.

[43] Salant, P., and Dillman, D.A. 1994. How to conduct your own survey. New York: Wiley

[44] Loring, P.A., Harrison, H.L, and S.C. Gerlach. 2013. Local Perceptions of the Sustainability of Alaska's Highly Contested Cook Inlet Salmon Fisheries. Society \& Natural Resources: An International Journal 0:1-15. DOI:10.1080/08941920.2013.819955

[45] Carothers, C. 2013. A survey of US halibut IFQ holders: Market participation, attitudes, and impacts. Marine Policy 39:515-522.

[46] Adams, V. Navigating trade-offs in land-use planning: integrating human wellbeing into objective setting. Ecology and Society 19:4

[47] Beardmore, B. 2015. Boater Perceptions of Environmental Issues Affecting Lakes in Northern Wisconsin. Journal of the American Water Resources Association 51(2): 537-549.

[48] Roche, LM Schohr, TK Derner, JD Lubell, MN Cutts, BB Kachergis, E Eviner, VT Tate, KW. 2015. Sustaining Working Rangelands: Insights from Rancher Decision Making. Rangeland ecology and management. 68(5):383-389. doi: 10.1016/j.rama.2015.07.006

[49] Pinkerton, E. 2013. Alternatives to ITQs in equity-efficiency-effectiveness trade- offs: How the lay-up system spread effort in the BC halibut fishery. Marine Policy, 42:5-13. doi:10.1016/j.marpol.2013.01.010 
[50] Christensen A, Hegland TJ, and G. Oddsson. 2009. The Icelandic ITQ system. In: Hauge KH, Wilson DC, editors. Comparative Evaluations of Innovative Fisheries Management. Springer Netherlands. 97-118.

[51] Pinkerton, E., and D. N. Edwards. 2009. The elephant in the room: the hidden costs of leasing individual transferable fishing quotas. Marine Policy 33(4): 70713. doi:10.1016/j.marpol.2009.02.004

[52] Anonymous. 2015. Ástand nytjastofna á Íslandsmiðum 2014/2015 og Aflahorfur fiskveiðiárið 2015/2016 (State of Marine Stocks in Icelandic Waters 2014/2015 and prospects for the quota year 2015/2016). Fjölrit nr. 182, Hafrannsóknastofnun (Marine Research Institute), Reykjavík, Iceland.

[53] Cook, R.M., Sinclair, A., and Stefansson, G. 1997. Potential collapse of North Sea cod stocks. Nature 385 (6616): 521-522. http://dx.doi.org/10.1038/385521a0

[54] Pálsson, Ó.K. 2003. A length based analysis of haddock discards in Icelandic fisheries. Fish. Res. 59: 437-446. doi:10.1016/S0165-7836(02)00017-6

[55] Kristofferson, D. and K. Rickertsen. 2005. High-grading in a quota-regulated fishery, with empirical evidence from the Icelandic cod fishery. XIth Congress of the EAAE, Copenhagen, Denmark, August 24-27.

[56] Anonymous. 2008, September 18. A rising tide. The Economist. http://www.economist.com/node/12253181

[57] Costello, C., Gaines, S.D., Lynham, J. 2008. Can Catch Shares Prevent Fisheries Collapse? Science 321 (5896): 1678-1681. DOI: 10.1126/science.1159478

[58] Copes, P. 2000. Adverse impacts of individual quota systems on conservation and fish harvest productivity. Simon Fraser University, Institute of Fisheries Analysis Discussion paper 00-2.

[59] Copes, P. 1986. A critical review of the individual quota as a device in fisheries management. Land economics, 62(3):278-291. http://www.jstor.org/stable/3146392

[60] Gilmour, P.W., R.W. Day, and P. D. Dwyer. 2012. Using private rights to manage natural resources: Is stewardship linked to ownership? Ecology and Society 17(3):1. http://dx.doi.org/10.5751/ES-04770-170301

[61] Van Putten, I., F. Boschetti, E. A. Fulton, A. D. M. Smith, and O. Thebaud. 2014. Individual transferable quota contribution to environmental stewardship: a theory in need of validation. Ecology and Society 19(2): 35 . http://dx.doi.org/10.5751/ES-06466-190235

[62] Essington, T. E. 2010. Ecological indicators display reduced variation in North American catch share fisheries. Proceedings of the National Academy of Sciences of the United States of America 107(2):754-759. http://dx.doi.org/10.1073/pnas.0907252107

[63] Essington, T. E., M. C. Melnychuk, T. A. Branch, S. S. Heppell, O. P. Jensen, J. S. Link, S. J. D. Martell, A. M. Parma, J. G. Pope, and A. D. M. Smith. 2012. Catch shares, fisheries, and ecological stewardship: a comparative analysis of resource responses to a rights-based policy instrument. Conservation Letters 5 (3):186-195. http://dx.doi.org/10.1111/j.1755-263X.2012.00226.

[64] Melnychuk, M. C., T. E. Essington, T. A. Branch, S. S. Heppell, O. P. Jensen, J. S. Link, S. J. D. Martell, A. M. Parma, J. G. Pope, and A. D. M. Smith. 2012. Can catch share fisheries better track management targets? Fish and Fisheries 13:267-290. http://dx.doi. org/10.1111/j.1467-2979.2011.00429.x

[65] Mansfield, B. 2004. Neoliberalism in the oceans: 'rationalization,' property rights, and the commons question. Geoforum 35(3): 313-326.

doi:10.1016/j.geoforum.2003.05.002 
[66] Foley, P., Mather, C., and Neis, B. Governing enclosure for coastal communities: Social embeddedness in a Canadian shrimp fishery. Marine Policy 61: 390-400. doi:10.1016/j.marpol.2014.11.009

[67] Mansfield, B. 2010. Modern industrial fisheries and the crisis of overfishing. Pp. 84-99 in Global Political Ecology, ed. R. Peet, P. Robbins, and M. Watts. New York: Routledge.

[68] Squires D., Kirkley J., and C. Tisdell. 2008. Individual transferable quotas as a fisheries management tool. Reviews in Fisheries Science 3(2): 141-169. doi:10.1080/10641269509388570

[69] Sumaila, U.R. 2010. A cautionary note on individual transferable quotas. Ecology and Society 15(3): 36. URL: http://www.ecologyandsociety.org/vol15/iss3/art36/

[70] Pálsson, G., and A. Helgason. 1996. The politics of production: enclosure, equity and efficiency. Pp. 60-86 in Images of Contemporary Iceland, ed. G. Palsson and P. Durrenburger. Iowa City: University of Iowa Press.

[71] Carothers, C., D.K. Lew, and J. Sepez. 2010. Fishing rights and small communities: Alaska halibut IFQ transfer patterns. Ocean \& Coastal Management 53(9): 518-523. doi:10.1016/j.ocecoaman.2010.04.014

[72] White, C.S. 2015. Getting into Fishing: Recruitment and Social Resilience in North Norfolk’s ‘Cromer Crab’ Fishery, UK. Sociologia Ruralis 55(3): 292-308. doi: 10.1111/soru.12101

[73] Sønvisen, S.A. 2013. Recruitment to the Norwegian fishing fleet: Storylines, paradoxes, and pragmatism in Norwegian fisheries and recruitment policy. Maritime Studies 12 (8) pp. 1-26. doi:10.1186/2212-9790-12-8

[74] Heiberger, RA HH: statistical analysis and data display: Heiberger and Holland. R package version 2.3-37, (http://CRAN.R-project.org/package=HH); 2013 [accessed 07.11.14].

[75] R Core Team. R: A language and environment for statistical computing. $\mathrm{R}$ Foundation for Statistical Computing.Vienna, Austria, (http://www.R-pro ject.org/); 2014 [accessed 07.11.14]. 
Thirty years after privatization: A survey of Icelandic small-boat fishermen

Catherine Chambers and Courtney Carothers

Figure 1: Schematic overview of Icelandic fisheries governance.

Figure 2: Percent agreement in response to selected Likert statements. Figure by J.M. Coleman using function 'likert' in package ' $\mathrm{HH}$ ' [74] in the statistical program $\mathrm{R}$ [75].

Figure 3: Survey responses to the multiple choice question: "What is the best management scheme for Icelandic small-boat fisheries?" All percentages reported are the proportion of total responses.

Figure 4: Percent agreement by fishery group to the Likert statement: "I have the flexibility to join other fisheries if my primary fishery is not doing well in any given season." Figure by J.M. Coleman using function 'likert' in package 'HH' [74] in the statistical program R [75]. 


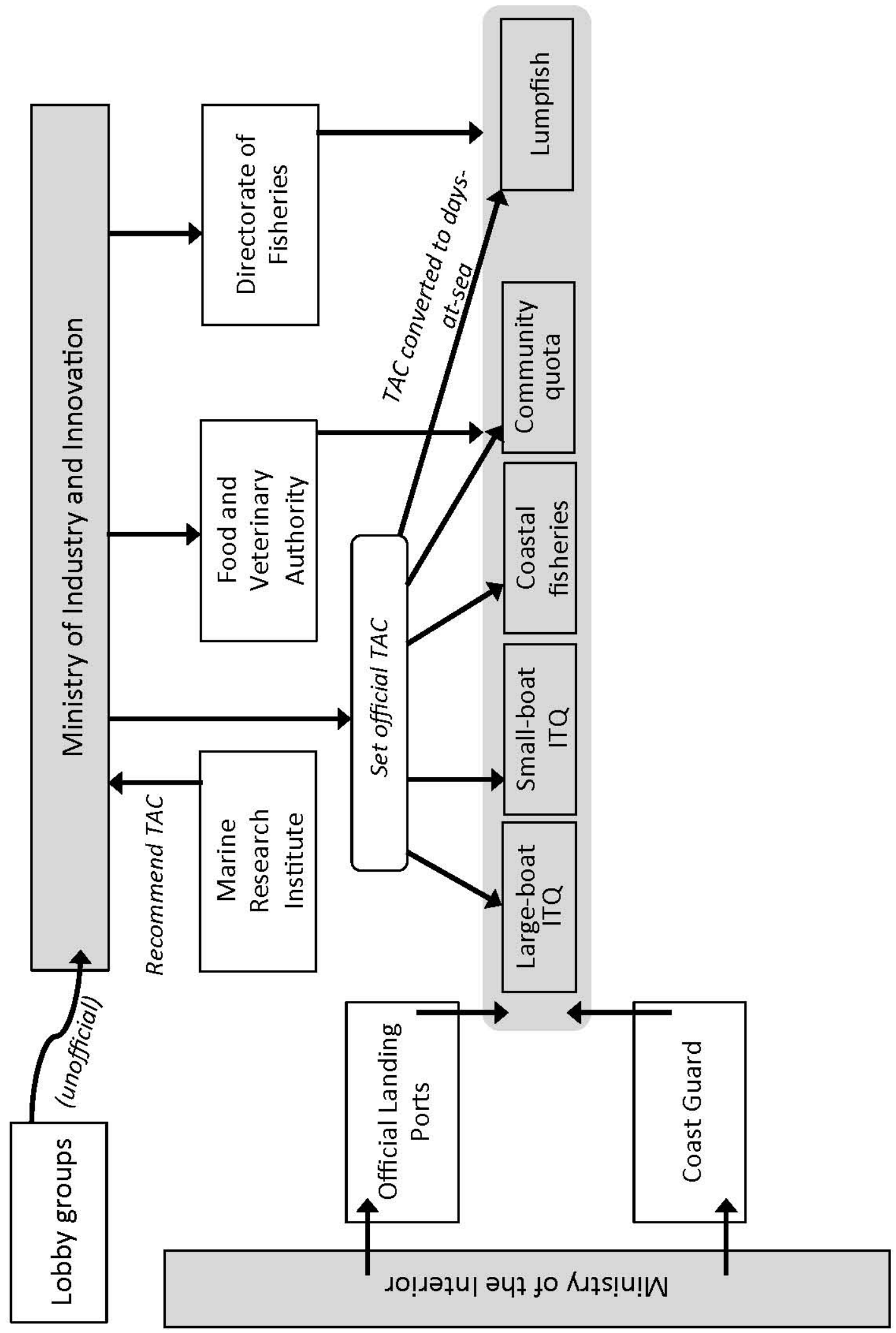


The government needs to consult with fishermen re: fisheries management

Ownership is the best way to protect fishery resources

Fisheries are a part of the Icelandic national identity

It is not possible to make enough money in fishing for the year outside the ITQ system

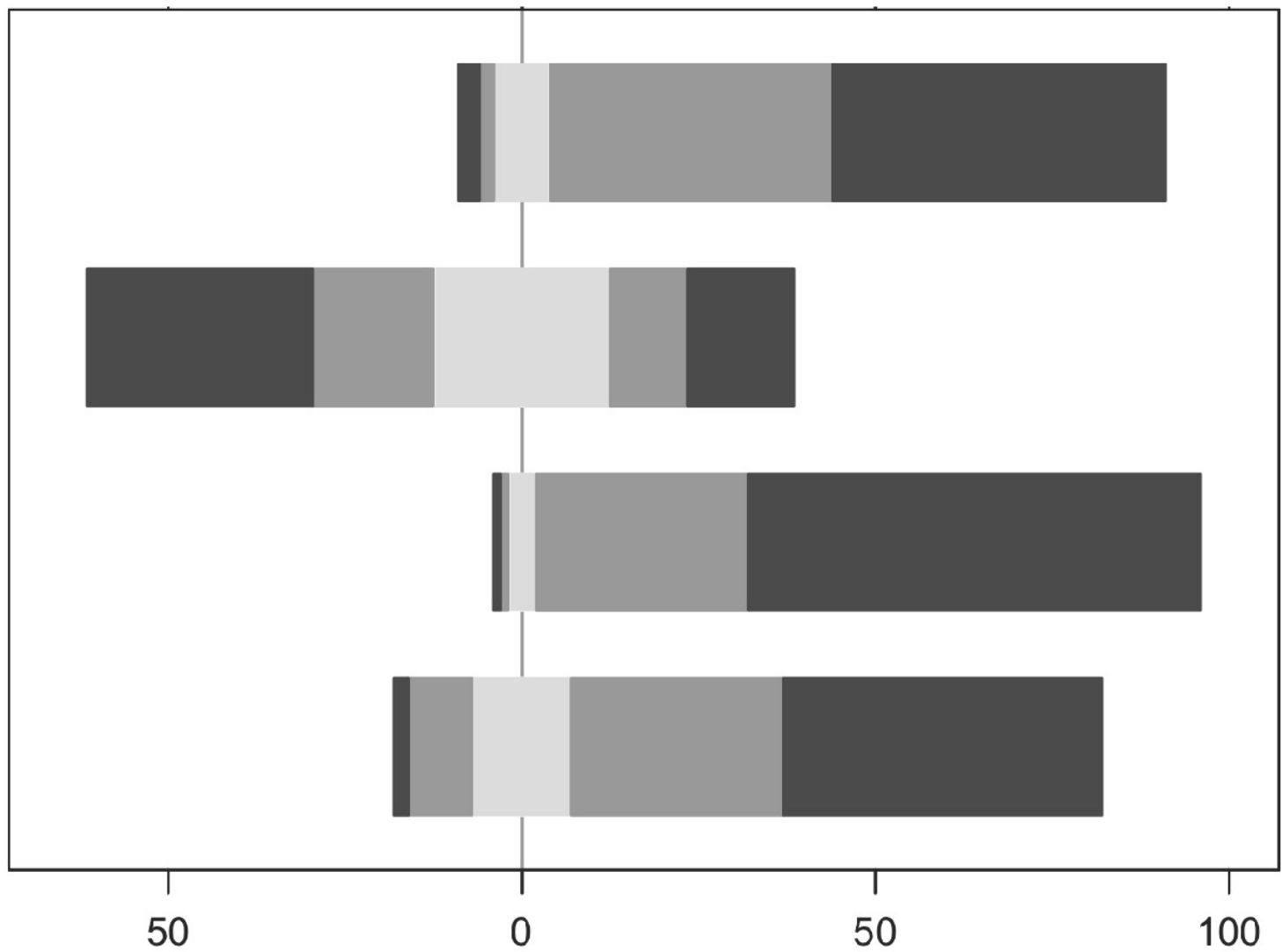

Percent Response 


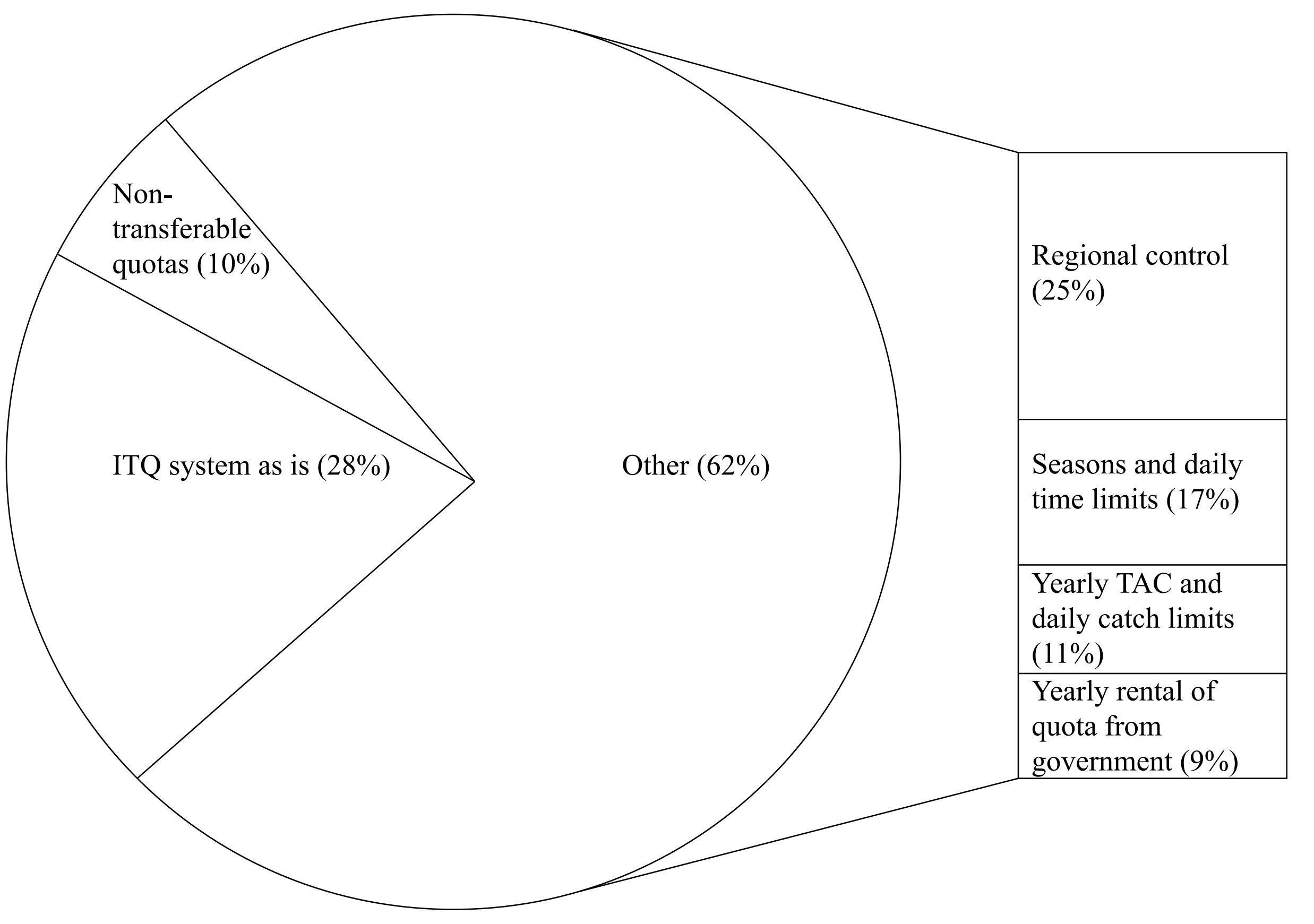




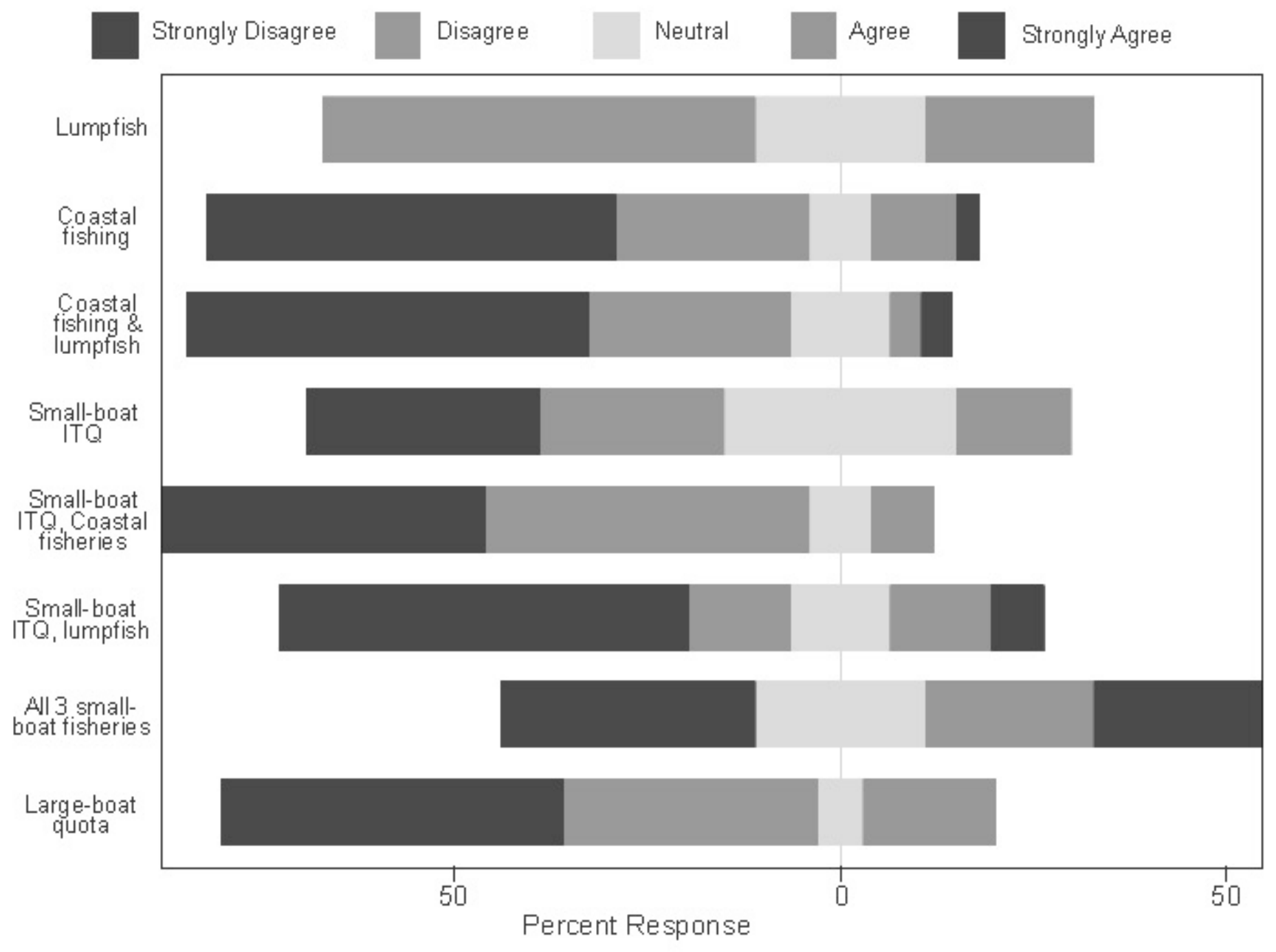


Table 1. Small-boat fisheries population, sample size and response rates for mailed survey. Surveys were returned from respondents in similar stratified percentages as were sampled.

\begin{tabular}{lcccc}
\hline & $\begin{array}{c}2012 \\
\text { database } \\
\text { total }\end{array}$ & $\begin{array}{c}\text { Surveys } \\
\text { sent }\end{array}$ & $\begin{array}{c}\text { Surveys } \\
\text { returned: } \\
\text { Self identified } \\
\text { primary fishery }\end{array}$ & $\begin{array}{c}\text { Surveys returned: } \\
2012-2013 \\
\text { fishing year } \\
\text { participation }\end{array}$ \\
\hline Primary Fishery & 1145 & 500 & 164 & 164 \\
Lumpfish & $142(12 \%)$ & $72(14 \%)$ & $12(7 \%)$ & $16(10 \%)$ \\
Coastal fishing & $460(40 \%)$ & $115(23 \%)$ & $38(23 \%)$ & $31(19 \%)$ \\
Lumpfish \& coastal fishing & $114(10 \%)$ & $80(16 \%)$ & $23(14 \%)$ & $19(12 \%)$ \\
Small-boat ITQ & $206(18 \%)$ & $94(19 \%)$ & $36(22 \%)$ & $23(14 \%)$ \\
Small-boat ITQ \& lumpfish & $133(12 \%)$ & $63(13 \%)$ & $15(9 \%)$ & $11(7 \%)$ \\
Small-boat ITQ \& coastal fishing & $48(4 \%)$ & $37(7 \%)$ & $13(8 \%)$ & $9(5 \%)$ \\
All three small-boat systems & $42(4 \%)$ & $39(8 \%)$ & $9(6 \%)$ & $9(5 \%)$ \\
Large-boat ITQ & Not sampled & $18(11 \%)$ & $46(28 \%)$ \\
\hline
\end{tabular}


Table 2: Mean satisfaction with current fisheries management by fishery type (median $=17$, mode $=17$, range $=7-33$, possible range $=7-35$ )

\begin{tabular}{lccc}
\hline Primary Fishery & Mean satisfaction & Number & Standard deviation \\
\hline All three small-boat systems & 15.22 & 9 & 6.92 \\
Lumpfish \& coastal fishing & 15.91 & 23 & 5.90 \\
Small-boat ITQ \& lumpfish & 16.13 & 15 & 4.84 \\
Coastal fishing & 16.34 & 38 & 5.24 \\
Lumpfish & 16.75 & 12 & 7.52 \\
Small-boat ITQ \& coastal fishing & 17.38 & 13 & 6.42 \\
Large-boat ITQ & 17.72 & 18 & 6.21 \\
Small-boat ITQ & 18.67 & 36 & 6.36 \\
\hline
\end{tabular}

